\title{
Level of physical activity, cardiorespiratory fitness and nutritional status of higher education institution servers
}

\author{
Nivel de atividade física, aptidão cardiorrespiratória e estado \\ nutricional de servidores de instituição de ensino superior
}

Leonardo Vidal Andreato, ${ }^{1}$ João Victor Del Conti Esteves, ${ }^{2}$ Tales de Carvalho,, Sabrina Weiss Sties, ${ }^{1}$ Daiane Pereira Lima, ${ }^{1}$ Solange Marta Franzói De Moraes ${ }^{3}$

IState University of Santa Catarina, Sciences Center of Health and Sport, Brazil.

ZLaboratory of Metabolism and Endocrinology, Institute of Biomedical Sciences, University of São Paulo, Brazil.

¿aboratory of Exercise Physiology, Department of Physiological Sciences, State University of Maringá, Brazil.

Recebido em: 09/11/2016 / Aceito em: 17/02/2017 / Publicado em: 31/03/2017

idal.leo@hotmail.com

\section{ABSTRACT}

Objective: to evaluate the level of physical activity, cardiorespiratory fitness and nutritional status of Brazilian higher education institution servers. Method: 134 public servants (80 men and 54 women) were evaluated to estimate body mass index (BMI), waist circumference (WC), waist/hip ratio (WHR), aerobic fitness and blood pressure at rest. Results: most of the servers were classified as insufficiently active (62\%). $B M I$ results show a high prevalence of obesity $139 \%$ mild and 33\% moderate). WC showed a prevalence of high (30\%) and very high risk (27\%), and WHR showed a prevalence of high (28\%) or very high risk (12\%). The ergometric test showed that $41 \%$ of the servers presented very poor (17\%) or poor (24\%) aerobic fitness and 23\%, regular aerobic fitness. Considering blood pressure, $15 \%$ of the servers presented blood pressure considered as borderline and 30\% considered as hypertension. No associations were found between physical condition (active or inactive) with $W C\left(\chi^{2}=3.4, p=\right.$ $0.179), W H R\left(\chi^{2}=7.0, p=0.073\right)$, aerobic fitness $\left(\chi^{2}\right.$ $=4.3, p=0.368)$ and blood pressure $\left(\chi^{2}=2.9, p=\right.$ $0.734)$. Although no association was observed between physical activity and BMI ( $\left.\chi^{2}=7.6, p=0.062\right)$, significance values ( $p<0.07)$ suggested an association trend, with worse ratings for the sedentary group. Closing remarks: among higher education institution servers, there is high prevalence of physical inactivity, obesity and risk factors, and the majority of the sample had aerobic fitness below recommended levels.

Keywords: Physical Activity; Sedentary; Non-communicable Diseases.

\section{RESUMO}

Objetivo: avaliar o nível de atividade física, aptidão cardiorrespiratória e estado nutricional de servidores de instituição de ensino superior. Método: 134 servidores (80 homens e 54 mulheres) foram avaliados para determinação do índice de massa corporal (IMC), circunferência de cintura (CC), relação cintura/quadril ( $R C Q)$, aptidão aeróbia e pressão arterial de repouso. Resultados: a maior parte dos servidores foi classificada como insuficientemente ativa (62\%). Os resultados de IMC demonstram alta prevalência de obesidade (39\% leve e $33 \%$ moderada). A CC mostrou alta prevalência de risco elevado (30\%) e muito elevado ( $27 \%$ ), e a RCQ apontou alta prevalência de risco alto (28\%) ou muito alto (12\%). O teste ergométrico apontou que $41 \%$ dos servidores apresentaram aptidão aeróbia muito fraca (17\%) ou fraca $(24 \%)$ e $23 \%$ regular. Considerando os níveis pressóricos, $15 \%$ dos servidores apresentaram pressão considerada limítrofe e $30 \%$ pressão considerada como hipertensão. Não foram encontradas associações entre condição física (ativo ou insuficientemente ativo) com CC $\left(\chi^{2}=3,4 ; p=0,179\right), \operatorname{RCO}\left(\chi^{2}=7,0 ; p=0,073\right)$, aptidão aeróbia $\left(\chi^{2}=4,3 ; p=0,368\right)$ e pressão arterial $\left(\chi^{2}=2,9 ; \mathrm{p}=0,734\right)$. Embora não tenha sido verificada associação entre nível de atividade física e IMC $\left(\chi^{2}=7,6 ; p\right.$ $=0,062)$, os valores de significância ( $p<0,07$ ) sugerem tendência de associação, com piores classificações para o grupo insuficientemente ativo. Considerações finais: entre servidores de instituição de nível superior há alta prevalência de inatividade física, obesidade e fatores de risco, bem como a maioria da amostra apresentou aptidão aeróbia abaixo dos níveis recomendados. 
Palavras-chave: Atividade física; Sedentarismo; Doenças crônicas não transmissíveis.

\section{INTRODUCTION}

Cardiovascular diseases are one of the leading causes of death worldwide. In Brazil these diseases are the main cause of death. ${ }^{2}$ Risk factors more evident in the panorama of cardiovascular health in Brazil are smoking, arterial hypertension systemic, diabetes mellitus, obesity, dyslipidaemia and sedentary lifestyle..$^{3,4}$ Among these risk factors for cardiovascular disease sedentary lifestyle appears to be one of the most important. ${ }^{5}$ Physical inactivity can be considered as the cause of 5.3 million deaths per year worldwide, representing approximately $10 \%$ of deaths. ${ }^{6}$

According to some studies ${ }^{7,8}$ changes in lifestyle, such as regular physical activity, represent a beneficial effect on major cardiovascular risk factors. Thus, small increases in the levels of physical activity in sedentary populations could represent a significant improvement with respect to reducing the incidence of diseases, especially cardiovascular diseases. ${ }^{1}$ However, the prevalence of physical inactivity is very high, even with the proven benefits of regular exercise. It is estimated that $31 \%$ of adults and $80 \%$ of adolescents worldwide do not meet the recommendations for physical activity. ${ }^{9}$ In Brazil about $80 \%$ of the population is sedentary..$^{10}$

Given this reality, incentive programs to promote physical activity for health reasons should be encouraged. In this scenario government institutions and particularly public universities play an important role in this process of awareness and combating physical inactivity.

In this context, it is relevant to check the level of physical activity, cardiorespiratory fitness and nutritional status of public servants at higher education institutions. It is hypothesized that these people are physically active with a good aerobic power associated with a low cardiovascular risk because they have greater access to information on the adoption of a healthy lifestyle. To test this hypothesis, the aim of this study was to evaluate the level of physical activity, cardiorespiratory fitness and nutritional status of higher education institution workers.

\section{METHOD}

\section{Participants}

This is a descriptive, cross-sectional study with non-probability sampling. The study sample consisted of 134 Brazilian higher education institution servers 180 men and 54 women), with an average age of $46.1 \pm$ 9.3 years old. Public servants were considered active if they reported being engaged in some systematized program of physical activity (e.g., walking, fitness, cycling, soccer) with a frequency less than or equal to twice a week. Participants were considered insufficiently active if they did not reach the established criteria. All servers were selected after outpatient screening at the university's medical clinic. Informed consent was obtained from all individual participants included in the study. All participants were informed about the study procedures, and all signed consent forms. This study was approved by the local ethics committee.

\section{Anamnesis}

A semi-structured questionnaire was used, with questions on aspects relating to personal data (e.g., age, sex), cardiovascular risk factors (e.g., arterial hypertension systemic, diabetes, dyslipidaemia, obesity, smoking), medical diagnosis (any disease), referent to the practice of regular physical activity (i.e., type, frequency, duration), knowledge of the benefits of exercise and, if not practiced, the reasons for not exercising.

\section{Anthropometry}

Body mass was measured using a commercial scale (Fillizola ${ }^{\circ}$ ) with a precision of $0.1 \mathrm{~kg}$, and height determined by a stadiometer (Seca ${ }^{\circ}$ ) with an accuracy of $0.1 \mathrm{~cm}$, according to the protocol described by Lohman et al. ${ }^{11}$. The circumference of the waist and hip were estimated using a tape measure Seca ${ }^{\oplus}$ with a precision of $0.1 \mathrm{~cm}$, following descriptions of Lohman et al. ${ }^{11}$

The Body Mass Index (BMI- weight $/$ height $^{2}-\mathrm{kg} / \mathrm{m}^{2}$ ) was determined according to the WHO classification. ${ }^{12}$ The waist/hip ratio (WHR = waist circumference $(\mathrm{cm}) /$ hip circumference $(\mathrm{cm})$ ); and the waist circumference (WC) were rated according to the WHO classification. ${ }^{12}$

\section{Blood pressure and ergometric test}

Blood pressure was checked using the auscultation method, following the parameters set by the VI Brazilian Guidelines on Hypertension. ${ }^{13}$ Aerobic power $\left(\mathrm{VO}_{2 \text { máx }} \mathrm{ml} / \mathrm{kg} / \mathrm{min}\right)$ was determined individually using an ergometric test on a treadmill (Inbrasport, Classic I, Porto Alegre-RS, Brazil), monitored by electrocardiogram (Ergo PC 3, Micromed, Brasília-DF, Brazil), following the protocol most appropriate for the assessed subject; the Bruce protocol and modified Bruce protocol were used. The classification of aerobic power was performed using reference values of the American Heart Association. ${ }^{14}$

\section{Statistical analysis}

Data are presented as mean, standard deviation, frequency and $95 \%$ confidence interval (95\% Cl). To analyse the association between variables, we used the chi-square test or Fisher's exact test when the conditions for the use of chi-square test were not checked. The level of significance was set at $5 \%$. Statistical analysis was carried out using the Statistical Package for the Social Sciences - SPSS software, version 20.0.

\section{RESULTS}

Anthropometric characteristics, cardiovascular risk factors and physical fitness of higher education institution servers are presented in table 1.

Data are presented as mean \pm standard deviation (95\% confidence interval). BMI: body mass index, WHR: waist/hip ratio, $\mathrm{VO}_{2 \text { máx }}=$ aerobic power, $\mathrm{SBL}=$ systolic blood pressure, $\mathrm{DBP}=$ diastolic blood pressure.

Considering the mean values, male and female participants presented BMls classified as light obesity, ${ }^{12}$ WC classified as elevated risk ${ }^{12}$ and blood pressure rated as normal. ${ }^{13}$ The WHR was classified as moderate 
Table 1 - Anthropometric characteristics, cardiovascular risk factors and physical fitness of higher education institution servers $(n=134)$.

\begin{tabular}{lccc}
\hline Variable & Male $(\mathbf{n}=\mathbf{8 0})$ & Female $(\mathbf{n}=\mathbf{5 4})$ & Overall $(\mathbf{n}=\mathbf{1 3 4})$ \\
\hline Age $($ years $)$ & $46.7 \pm 10.4(44.4-49.0)$ & $45.2 \pm 7.2(43.3-47.1)$ & $46.1 \pm 9.3(44.5-47.6)$ \\
Body mass $(\mathrm{kg})$ & $81.3 \pm 13.8(78.2-84.3)$ & $71.8 \pm 15.2(67.7-75.8)$ & $77.4 \pm 15.1(74.9-80.0)$ \\
Height $(\mathrm{m})$ & $1.72 \pm 0.08(1.70-1.73)$ & $1.58 \pm 0.06(1.57-1.60)$ & $1.66 \pm 0.09(1.65-1.68)$ \\
BMI $\left(\mathrm{kg} / \mathrm{m}^{2}\right)$ & $27.6 \pm 4.4(26.7-28.6)$ & $28.6 \pm 5.7(27.1-30.1)$ & $28.0 \pm 5.0(27.2-28.9)$ \\
Waist $(\mathrm{cm})$ & $94.2 \pm 10.1(92-96.5)$ & $85.6 \pm 12.5(82.3-88.9)$ & $90.7 \pm 11.9(88.6-92.7)$ \\
Hip $(\mathrm{cm})$ & $102.7 \pm 7.9(100.9-104.4)$ & $105.4 \pm 10.3(102.7-108.1)$ & $103.8 \pm 9.0(102.3-105.3)$ \\
WHR & $0.91 \pm 0.07(0.90-0.93)$ & $0.81 \pm 0.07(0.79-0.83)$ & $0.87 \pm 0.09(0.86-0.88)$ \\
VO ${ }_{2 \text { máx }}(\mathrm{ml} / \mathrm{kg} / \mathrm{min})$ & $31.4 \pm 11.3(28.9-34.0)$ & $25.1 \pm 8.2(22.8-27.4)$ & $28.9 \pm 10.7(27.0-30.8)$ \\
SBP $(\mathrm{mmHg})$ & $129.9 \pm 19.2(125.6-134.1)$ & $127.1 \pm 16.6(122.4-131.8)$ & $128.8 \pm 18.3(125.7-132.0)$ \\
DBP $(\mathrm{mmHg})$ & $79.6 \pm 8.3(77.7-81.4)$ & $80.3 \pm 10.0(77.5-83.2)$ & $79.8 \pm 9.0(78.3-81.4)$ \\
\hline
\end{tabular}

Data are presented as mean \pm standard deviation (95\% confidence interval). BMI: body mass index, WHR: waist/hip ratio, VO2máx $=$ aerobic power, SBL $=$ systolic blood pressure, $D B P=$ diastolic blood pressure.

Table 2 - Associations between sex and physical activity level in higher education institution servers

\begin{tabular}{lccc}
\hline & \multicolumn{2}{c}{ Physical activity level } & \\
\cline { 2 - 3 } Sex & Insufficiently active & Active & Total \\
\hline Female & 45 & 35 & 80 \\
Male & 38 & 16 & 54 \\
Total & 83 & 51 & 134 \\
\hline
\end{tabular}

Data are presented as frequency.

Table 2 - Associations between sex and physical activity level in higher education institution servers.

\begin{tabular}{|c|c|c|c|}
\hline & $\begin{array}{l}\text { sufficiently active } \\
(\mathbf{n}=83)\end{array}$ & $\begin{array}{c}\text { Active } \\
\text { (n = 51) }\end{array}$ & $\begin{array}{c}\text { Overall } \\
(\mathrm{n}=134)\end{array}$ \\
\hline \multicolumn{4}{|c|}{ ( } \\
\hline Underweight & $1.2 \%$ & $0 \%$ & $0.7 \%$ \\
\hline Normal & $26.8 \%$ & $25.0 \%$ & $26.1 \%$ \\
\hline Light obesity & $30.5 \%$ & $51.9 \%$ & $38.8 \%$ \\
\hline Moderate obesity & $39.0 \%$ & $23.1 \%$ & $32.8 \%$ \\
\hline Severe obesity & $2.4 \%$ & $0 \%$ & $1.5 \%$ \\
\hline Total & $100 \%$ & $100 \%$ & $100 \%$ \\
\hline \multicolumn{4}{|l|}{ WC } \\
\hline Normal risk & $36.6 \%$ & $52.0 \%$ & $42.4 \%$ \\
\hline Elevated risk & $31.7 \%$ & $28.0 \%$ & $30.3 \%$ \\
\hline Very elevated risk & $31.7 \%$ & $20.0 \%$ & $27.3 \%$ \\
\hline Total & $100 \%$ & $100 \%$ & $100 \%$ \\
\hline \multicolumn{4}{|l|}{ WHR } \\
\hline Low & $25.6 \%$ & $10.0 \%$ & $19.7 \%$ \\
\hline Moderate & $32.9 \%$ & $52.0 \%$ & $40.2 \%$ \\
\hline High & $28.0 \%$ & $28.0 \%$ & $28.0 \%$ \\
\hline Very high & $13.4 \%$ & $10.0 \%$ & $12.1 \%$ \\
\hline Total & $100 \%$ & $100 \%$ & $100 \%$ \\
\hline \multicolumn{4}{|l|}{$\mathrm{VO}_{2 \text { máx }}$} \\
\hline Very poor & $21.1 \%$ & $10.0 \%$ & $16.7 \%$ \\
\hline Poor & $21.1 \%$ & $28.0 \%$ & $23.8 \%$ \\
\hline Regular & $25.0 \%$ & $20.0 \%$ & $23.0 \%$ \\
\hline Good & $27.6 \%$ & $32.0 \%$ & $29.4 \%$ \\
\hline Excellent & $5.3 \%$ & $10.0 \%$ & $7.1 \%$ \\
\hline Total & $100 \%$ & $100 \%$ & $100 \%$ \\
\hline \multicolumn{4}{|l|}{ Blood pressure } \\
\hline Great & $22.4 \%$ & $16.3 \%$ & $20.0 \%$ \\
\hline Normal & $30.3 \%$ & $40.8 \%$ & $34.4 \%$ \\
\hline Limitrophe & $15.8 \%$ & $14.3 \%$ & $15.2 \%$ \\
\hline Stage 1 hypertension & $25.0 \%$ & $20.4 \%$ & $23.2 \%$ \\
\hline Stage 2 hypertension & $5.3 \%$ & $4.1 \%$ & $4.8 \%$ \\
\hline Stage 3 hypertension & $1.3 \%$ & $4.1 \%$ & $2.4 \%$ \\
\hline Total & $100 \%$ & $100 \%$ & $100 \%$ \\
\hline
\end{tabular}

Data are presented as \%. BMI: body mass index, WC: waist circumference, WHR: waist/hip ratio, $\mathrm{VO}_{2 \max }$ : aerobic power. risk for men and high risk for women. ${ }^{12}$

Table 2 shows that no significant association was found between sexes and physical activity level $\left(\chi^{2}=\right.$ 2.7, $\mathrm{p}=0.099$ )

Table 3 shows the values of the associations between physical activity level (insufficiently active or active) and $\mathrm{BMI}, \mathrm{WHR}, \mathrm{VO}_{2 \max }$ and blood pressure.

No associations were found between physical activity level (insufficiently active or active) and WC $\left(\chi^{2}\right.$ $=3.4, p=0.179), \operatorname{WHR}\left(\chi^{2}=7.0, p=0.073\right)$, aerobic power $\left(\chi^{2}=4.3, p=0.368\right)$ and blood pressure $\left(\chi^{2}\right.$ $=2.9, \mathrm{p}=0.734)$. Although an association between physical activity level and $\mathrm{BMI}\left(\chi^{2}=7.6, \mathrm{p}=0.062\right)$ has not been verified, the values of significance $(p<$ 0.07 ) suggest an association trend, with worse classifications for the insufficiently active group.

Additionally, it must be stressed that when individuals were asked in the interview if they knew the benefits of regular physical activity, the majority (99\%) answered in the affirmative and the main reasons for not participating in a systematic program was the limitation of time, followed by a lack of motivation/laziness.

\section{DISCUSSION}

In modern societies inactivity levels have increased significantly in recent years due to technological advances. This prevalence of lifestyle becomes harmful to health because physical inactivity is considered a primary risk factor for several diseases, including cardiovascular diseases, which is the main cause of death in Brazil. $^{2}$ In the present study we observed the presence of physical inactivity in $62 \%$ of participants, without noting a significant difference between the sexes.

In previous studies, similar results were observed among Brazilian college students, with studies finding that $51 \%$ of students did not perform physical activities at leisure in 2010. ${ }^{15}$ These findings in the university community do not differ from other populations. In 2013 it was observed that only $38 \%$ of adults in the capital of southern Brazil were considered active during leisure. ${ }^{16}$ This pattern of physical inactivity does not seem to be improving. In 2012 it was observed that, in a Brazilian city (Pelotas-RS), the prevalence of physical inactivity was $54 \%$, significantly higher than ten years ago. ${ }^{17}$ This pattern of behaviour deserves attention because today a sedentary lifestyle can be considered to be the 
cause of millions of deaths worldwide at a rate similar to deaths resulting from smoking. ${ }^{6}$ Besides, one of the detriments of the high index of physical inactivity is the increase in overweight and obesity rates, and this fact is considered a serious problem because excess body fat is associated with the development of diseases such as hypertension, dyslipidaemia, atherosclerosis, insulin resistance and type 2 diabetes, and non-alcoholic fatty liver disease, among others. ${ }^{18-20}$ However, even with constant disclosure of this information, there is a high prevalence of obesity and overweight rates.

In the present study only $26.1 \%$ of participants were classified as having a normal nutritional status. Most participants presented as obese $(38.8 \%$ with light obesity levels and $32.8 \%$ with moderate obesity) based on evaluation of the BMI. These results are similar to those of the Brazilian population; in 2013 it was estimated that in the population older than 20 about $52.5 \%$ of men and $58.4 \%$ of women presented as overweight or obese. ${ }^{21}$ Moreover, findings in the current study suggest an association trend with worse classifications for the insufficiently active group. Although use of $\mathrm{BMI}$ has its limitations, such as not differentiating the constituent tissues of body composition which is an important factor in determining health risk, it is effective for epidemiological studies and has been widely used in the evaluation and diagnosis of the nutritional status of people in worldwide. ${ }^{22}$ In fact, the literature has identified the relationship between the relative risk of total mortality and $\mathrm{BMI}$, with the two extremes of the index $1<20 \mathrm{~kg} / \mathrm{m}^{2}$ and $>30 \mathrm{~kg} / \mathrm{m}^{2}$ ) being associated with increased risk of morbidity and mortality. ${ }^{22,23}$ Lower $\mathrm{BMI}$ values are associated with tuberculosis, lung cancer and chronic obstructive pulmonary disease, while higher values are associated mainly with cardiovascular diseases, hypertension, diabetes, stroke, and in men, colon cancer. ${ }^{23}$

Besides BMI, waist circumference is another low-cost, easy-to-use parameter for predicting risk for cardiovascular and metabolic disorders. ${ }^{24}$ This method is an indicator of central obesity and is associated with other risk factors such as increase of insulin resistance. ${ }^{25} \mathrm{In}$ this study $42 \%$ of the sample showed normal risk while $30 \%$ showed high risk and $27 \%$ very high risk. The major concern of the evaluation is high fat deposits in the abdominal area (abdominal or visceral obesity) because this type of obesity is a more serious cardiovascular risk factor and disturbance in glucose-insulin homeostasis than generalized obesity. ${ }^{19}$

Central obesity verified by the WC also can be evaluated by WHR, which is an easy and useful tool for diagnosing risk factors for developing of health problems such as endocrine-metabolic, ${ }^{26}$ neoplastic ${ }^{27}$ and especially cardiovascular ${ }^{28}$ disorders. In the present research most participants showed a WHR rated as low and moderate. However, $40 \%$ presented with a WHR classified as high $(28 \%)$ or very high $(12 \%)$.

In addition to the anthropometric measurements, the evaluation of cardiorespiratory fitness is important in cardiovascular evaluation because low $\mathrm{VO}_{2 \max }$ values are correlated with mortality. ${ }^{29}$ Maximum oxygen consumption is a reproducible measure which expresses the maximum amount of oxygen that the body can use during exercise for the production of energy because during exercise there is an integration of the respiratory, cardiovascular and neuromuscular systems. ${ }^{30}$

In the present study $41 \%$ of participants presented aerobic power classified as very poor or poor, $23 \%$ as regular and $36 \%$ as good or excellent. There was no association between physical condition and aerobic power. In this sense, it may be suggested that the activities performed by the active group might not be enough quantitatively or qualitatively to generate benefits to its practitioners. In this sense, it is known that variables such as intensity, volume, frequency and type of exercise are important to tracking the changes in cardiorespiratory capacity; however, as a limitation of the study, these variables were not controlled.

Another cardiovascular risk factor is high blood pressure, which can be described as a clinical condition characterized by high and sustained blood pressure, ${ }^{13}$ representing a risk factor for many diseases, particularly those that affect the heart. ${ }^{18}$ Using the classification table of the VI Brazilian Guidelines on Hypertension, ${ }^{13}$ the group analysed in this research was not classified as hypertensive. When values were analysed as a percentage, however, $15 \%$ had blood pressure considered as limitrophe and $30 \%$ as hypertensive. In this sense, studies such as those of Fagard, ${ }^{5}$ have shown the importance of having a more active lifestyle as a method of prophylaxis of cardiovascular diseases, particularly hypertension. Also according Fagard, active individuals present a risk of developing hypertension approximately $30 \%$ lower than sedentary individuals.

In the current study most participants (99\%) reported knowing the benefits of regular physical activity. However, although the evaluated individuals were aware of the importance of regular physical activity, this knowledge did not cause them to change their physical condition from insufficiently active to active. Thus, the results obtained in this study refute the initial hypothesis, which predicted that the participants being in an environment that encourages the adoption of a healthy lifestyle, would be physically active, with good aerobic power associated with a low cardiovascular risk. This hypothesis was formulated especially for public servants at a state university which, at the time of data collection, had six campuses with 52 undergraduate courses, 93 specialization, and 28 master's degree and 12 doctoral degree programmes. Of these, six graduate courses, several specializations, and six master's and two doctoral degree programmes are related to health sciences.

\section{CLOSING REMARKS}

In summary, the findings might suggest that the universities have much to be desired in respect to physical activity of its employees. Primarily, universities are supported by the idea of a so-called tripod system, which should work in teaching, research and extension. The fact that the university community does not have better prevalence rates of physical activity and/or cardiovascular risk factors, per se, should be cause for reflection. It is essential that universities adopt strategies that would not only raise awareness about the benefits of regular physical activity but also awareness of the 
harmful effects of the absence of physical activities, and encourage the practice of exercise through safe and especially pleasurable activities.

\section{REFERENCES}

1. Perk J, De Backer G, Gohlke H, Graham I, Reiner Z, Verschuren WM, et al. European Guidelines on cardiovascular disease prevention in clinical practice (version 2012): The Fifth Joint Task Force of the European Society of Cardiology and Other Societies on Cardiovascular Disease Prevention in Clinical Practice (constituted by representatives of nine societies and by invited experts). Eur Heart J 2012;33:1635-701.

2. Ishitani LH, Franco GC, Perpétuo IHO, França R. Desigualdade social e mortalidade precoce por doenças cardiovasculares no Brasil. Rev Saúde Pública 2006;40:684-91.

3. Global Recommendations on Physical Activity for Health. WHO Guidelines Approved by the Guidelines Review Committee. Geneva 2010.

4. Sociedade Brasileira de Cardiologia. IV Diretriz Brasileira Sobre Dislipidemias e Prevenção da Aterosclerose. Departamento de Aterosclerose da Sociedade Brasileira de Cardiologia. Arq. Bras. Cardiol 2007;88:2-19.

5. Fagard RH. Physical activity, physical fitness and the incidence of hypertension. J Hypertens 2005;23:265-267.

6. Lee IM, Shiroma EJ, Lobelo F, Puska P, Blair SN, Katzmarzyk PT; Lancet Physical Activity Series Working Group. Effect of physical inactivity on major non-communicable diseases worldwide: an analysis of burden of disease and life expectancy. Lancet 2012;380:219-29.

7. Kivimäki $M$, Shipley $M J$, Ferrie JE, Singh-mannoux $A$, Batty GD, Chandola T, et al. Best-practice interventions to reduce socioeconomic inequalities of coronary heart disease mortality in UK: a prospective occupational cohort study. Lancet 2008;8:1648-54.

8. Steffen PR, Sherwood A, Gullette ECD, Georgiades A, Hinderliter A, Blumenthal JA. Effects of exercise and weight loss on blood pressure during daily life. Med Sci Sports Exerc 2001;33:1635-40.

9. Hallal PC, Andersen LB, Bull FC, Guthold R, Haskell W, Ekelund U; Lancet Physical Activity Series Working Group. Global physical activity levels: surveillance progress, pitfalls, and prospects. Lancet 2012;380:247-57.

10. Sociedade Brasileira de Cardiologia. Atlas corações do Brasil. São Paulo: Sociedade Brasileira de Cardiologia, 2005.

11. Lohman TG, Roche AF, Martorell R. Anthropometric Standardization Reference Manual. Champaign: Human Kinetics, 1988

12. World Health Organization. Obesity: Preventing and managing the global epidemic. Geneva : World Health Organization, 1997.

13. Sociedade Brasileira de Cardiologia / Sociedade Brasileira de Hipertensão / Sociedade Brasileira de Nefrologia. VI Diretrizes Brasileiras de Hipertensão. Arq. Bras. Cardiol 2010;95:1-51.

14. Heyward VH, Stolarczyk LM. Avaliação da Composição Corporal Aplicada. São Paulo: Manole, 2000.

15. Pirajá GA, Sousa TF, Fonseca AS, Barbosa AR, Nahas MV.
Autoavaliação positiva de estresse e prática de atividades físicas no lazer em estudantes universitários brasileiros. Rev Bras Ativ Fis Saúde 2013;18:740-9.

16. Rech CE, Reis RS, Hino AAF, Sá GBR, Stopa SR, Malta DC. Tendências temporais de indicadores de atividade física e comportamento sedentário nas capitais da Região Sul do Brasil: 2006-2013. Rev Bras Ativ Fís Saúde 2015;20:47-56.

17. Hallal PC, Cordeira K, Knuth AG, Mielke Gl, Victora CG. Ten-year trends in total physical activity practice in Brazilian adults: 2002-2012. J Phys Act Health 2014;11:1525-30.

18. Jensen MD. Role of Body Fat Distribution and the Metabolic Complications of Obesity. J Clin Endocrinol Metab 2008; 93:57-63.

19. Meshkani R, Adeli K. Hepatic insulin resistance, metabolic syndrome and cardiovascular disease. Clin Biochem 2009;42:1331-46.

20. Ojeika Vasques, M, Vidal Andreato L, Almeida, FN, Del Conti Esteves, JV, Fernandes De Souza R, Franzói De Moraes SM. Strength training improves plasma parameters, body composition and liver morphology in ovariectomized rats. Science \& Sports 2012;27:94-100.

21. Ng M, Fleming $T$, Robinson $M$, Thomson B, Graetz $N$, Margono C, et al. Global, regional, and national prevalence of overweight and obesity in children and adults during 19802013: a systematic analysis for the Global Burden of Disease Study 2013. Lancet 2014;384:766-81.

22. Janssen I. Infuence of age on the relation between waist circumference and cardiometabolic risk markers. NMCD 2009;19:163-69.

23. Waaler HT. Hazard of obesity: the Norweigian experience. Acta Med Scand Suppl 1988;723:17-21.

24. Sarrafzadegan N, Kelishadi R, Siadat ZD, Esmaillzadeh A, Solhpour A, Shirani S, et al. Obesity and cardiometabolic risk factors in a representative population of Iranian adolescents and adults in comparison to a Western population: the Isfahan Healthy Heart Programme. Public Health Nutr 2010;13:314-323.

25. Park K, Lee D, Erickson DJ, Himes JH, Shikany JM, Jacobs DR. Association of long-term change in waist circumference with insulin resistance. Obesity 2009;18:370-376.

26. Despres JP, Lemieux I. Abdominal obesity and metabolic syndrome. Nature 2006;7121:821-27, 2006.

27. Zhang C, Rexrode KM, Van dam RM, Li TH, Hu FB. Abdominal obesity and the risk off all-cause, cardiovascular, and cancer mortality sixteen years of follow-up in US women. Circulation 2008;17:1658-67.

28. Taylor AE, Ebrahim S, Ben-shlomo $Y$, Martin RM, Whincup $\mathrm{PH}$, Yarnell JW, et al. Comparison of the associations of body mass index and measures of central adiposity and fat mass with coronary heart disease, diabetes, and all-cause mortality: a study using data from 4 UK cohorts. Am J Clin Nutr 2010;91:547-556.

29. Myers J, Prakash M, Froelicher V, Do D, Partington S, Atwood JE. Exercise capacity and mortality among men referred for exercise testing. N Engl J Med 2002;346:793-801.

30. Armstrong N, Welsman JR. Peak oxygen uptake in relation to growth and maturation in 11 to 17 years old humans. Eur $\mathrm{J}$ Appl Physiol 2001;85:546-551.

Como citar: ANDREATO, Leonardo Vidal et al. Level of physical activity, cardiorespiratory fitness and nutritional status of higher education institution servers. Cinergis, Santa Cruz do Sul, v. 18, n. 2, mar. 2017. ISSN 2177-4005. Disponível em: < https://online. unisc.br/seer/index.php/cinergis/article/view/8585>. Acesso em: 29 mar. 2017. doi:http://dx.doi.org/10.17058/cinergis.v18i2.8585. 